https://doi.org/10.1590/198053145794

\title{
NET COSTS OF CLASS-SIZE REDUCTION: THE PORTUGUESE CASE*
}

\author{
Pedro Ribeiro Mucharreira' \\ Belmiro Gil Cabrito" \\ Luís Capuchal"! \\ TRANSLATED BY Lyn Miller-Lackman'v
}

\begin{abstract}
This article aims to promote further reflection on the benefits derived from class-size reduction, seeking to demonstrate that the expenditures resulting from this are usually overestimated when they are determined on the basis of gross employee cost to the State, and not taking into account the corresponding net costs. This scholarly exercise analyzes the Portuguese case and the costs of a teacher in the public education system in Portugal. This work intends to contribute to a better understanding of this subject, raising awareness of different educational actors of the relationship between cost and direct and indirect benefits of a class-size reduction policy.
\end{abstract}

EDUCATIONAL POLICIES • CLASS SIZE • COSTS • PORTUGAL

CUSTOS LÍQUIDOS DECORRENTES DA REDUÇÃO DO NÚMERO DE ALUNOS POR TURMA: O CASO PORTUGUÊS

\section{Resumo}

O presente artigo pretende promover a reflexão em torno dos beneficios decorrentes da diminuição do número de alunos por turma, procurando, neste sentido, demonstrar que as despesas daqui resultantes são habitualmente sobrevalorizadas ao serem determinadas em função dos custos brutos de um trabalhador para o Estado e não tendo em conta os custos líquidos correspondentes. Para este exercício académico, levou-se em linha de conta o caso português e os custos de um professor para o sistema público de ensino em Portugal. Com este trabalho pretende-se contribuir para uma melhor reflexão sobre esta temática, sensibilizando diferentes atores educativos para uma aproximação mais fina à relação entre custos e benefícios diretos e indiretos que podem resultar de uma política de redução do número de alunos por turma.

POLÍTICAS EDUCACIONAIS • DIMENSÃO DAS CLASSES • CUSTOS • PORTUGAL

\footnotetext{
* The translation of this paper was supported by Portuguese national funds through FCT- Fundação para a Ciência e a Tecnologia, I.P., in the scope of the project reference UID/SOC/03126/2019.

I Instituto de Educação, Universidade de Lisboa, Lisboa, Portugal; http://orcid.org/0000-0003-0059-0576; prmucharreira@ie.ulisboa.pt

II Instituto de Educação, Universidade de Lisboa, Lisboa, Portugal; http://orcid.org/0000-0003-0420-5639; b.cabrito@ie.ulisboa.pt

III Instituto Universitário de Lisboa (ISCTE-IUL), Lisboa, Portugal; http://orcid.org/0000-0002-4173-9309;

luis.capucha@iscte-iul.pt

IV Freelancer; Iynm/@me.com
} 


\section{COÛTS NETS DÉCOULANT DE LA RÉDUCTION DU NOMBRE D'ÉLĖVES PAR CLASSE : LE CAS DU PORTUGAL}

\section{Résumé}

Cet article vise à favoriser la réflexion sur les avantages de la diminution du nombre d'élèves par classe. En ce sens, il cherche à démontrer que les coûts qui en résultent sont en général surestimés car calculés d'après les coûts bruts qu'un travailleur représente pour l'état, sans prendre en considération les coûts nets correspondants. Cet exercice académique concerne le cas du Portugal et le coût d'un enseignant dans le système scolaire public de ce pays. Notre objectif est d'approfondir la réflexion sur la question pour sensibiliser les différents acteurs de l'éducation à une l'approche plus fine concernant le rapport entre coûts et bénéfices directs et indirects d'une politique de réduction du nombre d'élèves par classe.

POLITIQUES ÉDUCATIVES • DIMENSION DE LA CLASSE • COÛTS • PORTUGAL

\section{COSTES NETOS DERIVADOS DE LA REDUCCIÓN DEL NÚMERO DE ALUMNOS POR CLASE: EL CASO PORTUGUÉS}

\section{Resumen}

El presente artículo pretende promover la reflexión en torno a los beneficios derivados de la disminución del número de alumnos por clase, procurando, en este sentido, demostrar que los gastos resultantes de ello son habitualmente sobrevalorados al ser determinados en función de los costes brutos de un trabajador para el Estado y no teniendo en cuenta los costes netos correspondientes. Para este ejercicio académico, se tuvo en cuenta el caso portugués y los costes de un profesor para el sistema de educación pública en Portugal. Con este trabajo se pretende contribuir a una mejor reflexión sobre esta temática, sensibilizando a diferentes actores educativos sobre una mejor aproximación a la relación entre costes y beneficios directos e indirectos que pueden resultar de una política de reducción del número de alumnos por clase.

POLÍTICAS EDUCATIVAS • DIMENSIÓN DE LA CLASE • COSTOS • PORTUGAL 
HIS ARTICLE AIMS TO PROMOTE FURTHER REFLECTION ON POLICIES RELATED TO education funding, particularly on the level of direct and indirect impacts of class-size reductions, using the Portuguese educational system as a case study.

In addition to reviewing the literature on this topic - particularly that which addresses the financial impacts of class-size reductions -, this article seeks to present a methodological path that will permit assuming some reference values for different stages of the teaching career.

One of the issues currently faced by educational systems, and by all public policies, is funding. In view of governments' increasing financial difficulties to meet the demands arising from the expansion of education, particularly compulsory education, it is difficult to propose reforms that, at least at first glance, will result in higher costs to the State.

One of the educational measures that has been promoted, or at least suggested, in developed countries is reducing the number of students per class, on the premise that smaller class sizes contribute to academic success.

Nonetheless, first and foremost, this initiative has been hindered by the fact that reducing the number of students per class entails extraordinary expenditures that threaten to strain States' limited budgets.

Obviously, at first glance, reducing the number of students per class means more classes and, consequently, requires larger investments in facilities 
and equipment, as well as in teachers, administrators, and technical staff. However, the action of dismissing that measure due to the financial burdens it may impose not only overlooks, in the short term, its positive pedagogical effects - increased school success and reduction in the costs of grade retention -, but also ignores, in the medium and long term, the spillover effect of a more educated population. In addition, dismissing class-size reduction measures due to their costs is to assume that one more teacher or one more employee will constitute an increased expense for the State, not an investment. Moreover, such expense is commonly overestimated.

In this article, first of all and drawing on the literature, we intend to highlight some of the benefits of reducing class sizes, and, second, to demonstrate that the expenses of doing so have been consistently overestimated when they are determined by the gross costs of a public employee rather than by the net costs.

In this scholarly exercise, we will take into account the Portuguese case and the costs of a teacher in the public education system in Portugal using figures from 2015-2016.

\section{THEORETICAL FRAMEWORK}

The issue of class size, both in terms of costs and in terms of educational work and school achievement, has been the subject of many studies, with conclusions that sometimes differ significantly. In spite of these disagreements, it is worth noting that the main reference studies point to the conclusion that smaller classes tend to produce more favourable pedagogical results, especially among students from socially disadvantaged backgrounds (KRUEGER, 2003; SERVE, 2005). In the Portuguese context, a recent study funded by the Ministry of Education highlighted similar findings (CAPUCHA et al., 2017).

In addition to improvements in student learning obtained in smaller classes, several studies also point to positive effects in school climate and teacher work (FINN; ACHILLES, 1999; KRUEGER, 2003; JEPSEN; RIVKIN, 2009; HARFITT, 2015; BLATCHFORD et al., 2016). Two other aspects on which scholars agree when studying class-size reduction policies are that they can never be viewed in isolation - rather, they should be viewed in conjunction with a range of educational policies - and that their implementation will require an increase in financial outlays, due primarily to the hiring of additional teachers and the construction or rehabilitation of classrooms.

Despite this, several authors refer to ways in which these associated costs can be lessened, in the medium and long term, by taking into account reductions in grade retention and dropout rates, the rising educational level of the population, and the consequent increase in economic productivity and purchasing power, and the reinforcement of equity and social justice, among other aspects that may generally promote economic growth and development. In this sense, the framework of these indirect benefits is the Theory of 
Human Capital (SCHULTZ, 1961; BECKER, 1964) and innumerable studies that demonstrate the positive relationship - a spillover effect - between educational levels and rising levels of economic growth and development (PSACHAROPOULOS, 1994; PSACHAROPOULOS; PATRINOS, 2004), as well the social and economic development resulting from other indirect and non-monetary benefits, such as changes in fertility and birth rates, the encouragement of political participation and solidarity, as well as crime reduction. All of these represent incalculable positive externalities of education. (WEALE, 1992; FARCHY; SAGOT-DUVAUROUX, 1994; WOLFE, 1995; WOLFE; ZUVEKAS, 1997; WOLFE; HAVEMAN, 2001).

In spite of these positive externalities that may occur in the medium and long term, the decision to reduce the number of students per class is a measure with immediate financial effects, resulting from the need to hire new teachers and more technical and operational support staff, as well as building, renovating, or reequipping classrooms. We see here the difficulty, from a financial point of view, of significantly reducing class sizes, taking into account the budgetary demands and constraints that schools face and the priority often given to the implementation of alternative educational programs (KRUEGER, 2003; SERVE, 2005).

Moreover, what usually ends up on the table of many political decision makers is precisely the opposite: in the name of budgetary control, raising the average number of students per class, with the goal of saving major sums of money. Another potential measure consists of promoting the rise in another related indicator, the student/teacher ratio. In this respect, and using the example of the American system, Whitehurst \& Chingos (2011) demonstrate that raising the student/teacher ratio by one student supposedly represents annual budgetary savings on the order of 12 billion dollars in teacher salaries alone, by reducing teacher hiring on the order of 7 percent.

Taking into account the benefits of a class-size reduction policy, authors such as Hanushek (1997), Normore \& Ilon (2006), and Whitehurst \& Chingos (2011) highlight the need to understand whether this policy will be the most cost-effective and appropriate in comparison with others, whether it will enable the best use of financial and budgetary resources for educational success, and ultimately support economic growth and development (MUCHARREIRA; ANTUNES, 2015).

On the other hand, there is an urgent need to include in the debate the costs inherent in not implementing policies that can promote adequate class sizes. As previously explained, it is certain that implementing class-size reduction measures may result in a significant increase in costs, but it is necessary to take into account the medium and long-term economic and social impacts, which may be higher, of the decision not to reduce the number of students per class. Such impacts include, for example, lower higher education graduation rates, lower productivity, lower average earnings, as well as negative impacts on civic participation and general happiness, all of which, taken together, will translate into lower fiscal returns for the State. In this sense, according to Krueger (2003), it is desirable, when legally viable, for regional or local educational decision 
makers to take the initiative in reducing class sizes, creatively combining different sources of funding from central, regional, and local governments, and reallocating human and technical resources.

This idea that educational expenditures end up generating a direct return for the community justifies the fact that public expenditures on education, which are mainly composed of personnel expenses and current operating expenses, are generally understood as investments or capital expenditures (SANT'OVAIA; REIS, 2008). Therefore, all expenditures that enable an improvement in the educational situation, such as smaller class sizes, should be considered an investment that will have a return, albeit over a longer period of time.

From the above, we can see that reducing class sizes can be more of a political decision than an educational one (KRUEGER, 1999), depending on the educational objectives that the government pursues. In fact, and in spite of the lack of political consensus, assuming that class-size reductions will lead to gains on the pedagogical level - demonstrated in indicators such as greater school success, fewer grade retentions, more meaningful learning, and better jobs in the future, among others -, one would expect decision-makers to reassess their priorities in educational administration.

In this discussion, other actors intrude, such as the media and, in a very particular way, families - the voters -, who a priori tend to welcome these types of policies, as they expect them to generate improvements in student learning (CHINGOS, 2012). In addition, teachers' unions tend to embrace these policies as a means of bringing about an increase in the number of teachers needed, and thus assume in this instance a role of a markedly political nature.

Of course, these conclusions assume that the total number of students remains stable, which is the case of countries where the population is still young or, if the population is maturing, where natural growth is still taking place. In places where the number of students is declining, as it will be the case in Portugal in the coming years due to the continued and severe decline in the birth rate, it will be possible to reduce class sizes without increasing - or perhaps even reducing - the total number of classes and classrooms needed. All of this will depend on the size of the reduction in the demand in each country, region, or school - a variable dependent on many factors, including demographic shifts.

\section{METHODOLOGY}

Bearing in mind the theoretical framework, we sought to estimate the gross and net costs resulting from the need to hire a new teacher, using the Portuguese case as an example. To this end, a survey and data analysis was used (BOGDAN; BIKLEN, 1994; BARDIN, 2009), drawing from the statistics of Direção-Geral de Estatísticas da Educação e Ciência [Director-General of Educational and Scientific Statisticss] (DGEEC), taking as its reference point the 2015-2016 school year.

It was our intention to create a simulation exercise tied to the possible need to hire new teachers, aiming to use the estimated values to assess the future 
financial impacts of class-size reductions, especially the impacts of the need to employ more human resources. Consequently, we shall now propose, make explicit and justify the methodology we considered appropriate to determine the unit cost per teacher in the event hiring is necessary as a result of a class-size reduction policy. However, it should be noted that for the other staff (operational and technical assistants), calculations would follow the same methodology.

Taking into account the theoretical framework presented above, we shall now explain how the cost of one additional teacher was calculated, according to values of the 2015-2016 academic year. For these calculations, it was necessary to begin with reasonably intelligible assumptions about on what basis those costs were determined.

1 - For each teacher, we considered not only that an individual at the beginning of his or her career would be hired, but also that a "schedule 0" teacher might take the place of a new hire - that is, in the Portuguese case, a certified teacher who has been assigned other educational or administrative tasks rather than classroom teaching due to a decrease in the number of students at that school. This justifies our choice to calculate a so-called "average salary". In this sense and with the goal of avoiding excessive complexity and proliferation of statistics which may influence analysis, we determined the financial impacts relative to two possible scenarios: one, utilizing Scale 167 of the teaching career, because it is the normal entry-level pay scale, and the other scenario, using the pay scale for the average salary that we calculated.

2 - Taken into account were all of the costs that each teacher entails to the State and that correspond to the State's expenses on that teacher.

3 - Taken into account were all of the direct and indirect returns that the State will receive from the salaries that it pays each employee, assuming here the State as an aggregate that goes beyond a simple system of government in order to encompass multiple systems managed by the State and that guarantee the well-being of the population and/or the State's performance of its social functions. As for direct returns, we assume the tax withholding by the State of the total salary of the employee, as the rate to be applied depends on the employee's base salary.

4 - Attention was given to the disposable income of each professional employee and his or her direct and indirect contributions to the State coffers in the form of taxes.

Our methodology for calculating the financial impacts of reducing the number of students per class is different from the ones normally utilized especially in Portugal by official entities such as Conselho Nacional de Educação [National Council of Education] (CNE) (PORTUGAL, 2016), taking into consideration the fact that each teacher is simultaneously an expense and a source of income for the State. The expense is the nominal salary that corresponds to each salary level. The source of income corresponds to the part of the salary that the State will claim indirectly by means of taxes and contributions. 
So how did we determine the real cost of an employee to the State? We added to the regular salary the $23.75 \%$ that the State, as an employer, pays per employee for Social Security, regardless of the employee's salary level. This sum is what an employee really costs the State; except that afterwards the State will claim a portion of the employee's nominal salary through the Personal Income $\operatorname{Tax}\left(\right.$ IRS) ${ }^{1}$ — contributions to Caixa Geral de Aposentações [Social Security] (CGA), and to the Instituto de Proteção e Assistência na Doença [Institute for Protection and Assistance in Illness] (ADSE). The sum of these parcels, that is, what the State collects, is no longer an expense for the State, because the worker in effect earns only the nominal salary, i.e., it is necessary to deduct the contributions that enter the State coffers by means of various agencies, which we consider "direct benefits" that return to the State. Next, we added the meal subsidy to the amount that the employee can effectively add to the income he or she has available to spend. The result corresponds to the worker's Disposable Income, that is, the amount the employee is, in fact, able to spend after the withholding of income taxes and other contributions.

Following this, we determined the returns/indirect benefits that the State will collect from the worker's salary. In order to do this, we took advantage of what the science of Economics can teach us. In Economics, disposable income serves two purposes: the acquisition of consumer goods (among them food, vehicles, etc.) and savings. According to Banco de Portugal, the individual savings rate, measured in the fourth quarter of 2015, is $3.6 \%$ of the disposable income. That is to say that $96.4 \%$ of individual disposable income corresponds to what each person has available to pay for durable and non-durable consumer goods and investments, which are, consequently, expenditures. However, there is an indirect tax on each expenditure, Value Added Tax (VAT), which is borne by the ultimate consumer. In this way, all of the workers (of the State or of any other employer) are the ultimate consumers, that is to say, they are the source of the State's income obtained by means of VAT. This means that part of the disposable income (that is, $96.4 \%$ of the disposable income, according to figures from the fourth quarter of 2015) of teachers is witheld by and sent directly to the State via VAT.

To determine this amount, we focus on the following question: Considering that there are multiple VAT rates, depending on the nature or category of consumer goods, how do we calculate this? Probably, the most correct form (with errors always associated with this type of calculation and that depend on the options taken) would be to verify the various types of consumption and to apply the corresponding tax rate to the value of each of these types. Unfortunately, the existing and/or available statistics do not allow a calculation of that nature by virtue of the inclusion, in the same heading, of goods that are taxed at different VAT rates. For example, in Inquérito às Despesas das Famílias [Household Survey] 
(IDEF) of Instituto Nacional de Estatística [National Statistics Institute] (INE), the first item is "food, beverages, and tobacco," which includes three very different types of consumer goods with different VAT rates. The question is even more complex both in this source and in others consulted, such as the scientific literature related to this topic, as there are several similar situations that do not permit us to determine the VAT paid by families to the State through the structure of consumption.

As a consequence, we decided to use Base de Dados Portugal Contemporâneo [Portugal Database] (PORDATA, 2018), which presents in the form of a breakdown the total revenue the State collected through direct and indirect taxes. Using Pordata (2018) figures, we verified the overall value of VAT collected by the State in 2015 from personal consumer expenditures, and we considered this value as the average VAT rate paid by families in that period, which corresponds to about 12.5\%. Let us observe the values below, drawn from Pordata (2018) for 2015-2016:

Disposable Individual Gross Income: 123,092.00 (million euros)

Individual savings rate $-3.6 \%$

Individual consumer spending - 118,660.68 (million euros)

VAT - 14,844.30 (million euros)

VAT/Consumer spending (average rate) - 12.5\%.

This means that through VAT the State receives $12.5 \%$ of the expenditures of the ultimate consumer. We did not take into account other more specific indirect taxes. This is how we determined the "indirect benefits" that the State receives from its employees when they spend the unsaved portions of their disposable income.

Therefore, a teacher actually costs the State approximately: (Nominal salary $+23.75 \%$ of salary for Social Security/CGA + meal subsidy) - direct returns (IRS, ADSE, Social Security/CGA) - indirect returns (VAT).

When we consider that part of the teachers' salary is sent back to the State through direct and indirect taxes, we determine how much, in fact, these professionals cost to the State.

Although more scientifically rigorous, this formula does not permit us to see the impact of hiring a teacher on the Budget that supports this hiring, that of the Ministry of Education.

Therefore, to determine the fiscal impact, we utilized two types of costs:

- Gross Costs, that is, the real cost of an employee for the Ministry of Education (ME), and that results from adding, to the nominal salary of an employee, the $23.75 \%$ of this salary that the ME sends to Social Security, and, along with it, the meal subsidy. We called this amount "Gross Annual Salary", which corresponds to the direct financial burdens borne by the Ministry of Education.

- Net Costs, obtained assuming that the employee is not only a source of expense, but also a source of income, as a result of the direct and indirect revenues drawn from the respective salary; we called this amount "Net Annual Salary," which corresponds, in the final instance, to the financial burdens on the State per employee. 
For each type of cost, Gross Annual Salary and Net Annual Salary, we present, in relation to teachers, two alternative salaries: the average salary of teachers currently serving and the amount that corresponds to Scale 167, the beginning step of the teaching career.

The average salary is drawn from the weighted average of the expenditures incurred by ME on teacher salaries in the 2015-2016 academic year, using data provided by the ME regarding the number of primary and secondary education teachers and their respective salary scales (from Scale 167, at the beginning of the teaching career, to Scale 340, at the end of the teaching career);

- The value corresponding to Scale 167 was used, based on the presumption that any new teacher will be hired at the beginning of the career.

In this framework, we now present the following four types of financial impacts related to teaching professionals:

- Average Gross Annual Teacher Salary;

- Average Net Annual Teacher Salary;

- Gross Annual Teacher Salary, Scale 167;

- Net Annual Teacher Salary, Scale 167.

\section{COSTS TO THE STATE AS A RESULT OF NEW HIRING}

Having taken into account the survey and analysis of the literature and the methodological procedures mentioned above, it was then possible to present the calculations that permited us to determine the gross costs - gross annual salary - and the net costs - net annual salary - that the State assumes with teachers of "average scale" and of Scale 167, utilizing data from 2015-2016. In these calculations it was necessary to take into account the nature of each IRS taxpayer, assuming in all cases two wage-earners with two dependent children, as that is the most frequent type of taxpayer among the actively employed Portuguese population and, by the same token, among teachers.

In this way, we present the calculations that allow us to calculate the reference values that can offer us more objectively the true financial impacts that a class-size reduction policy has upon the Portuguese educational system. In Table 1, we find the number of teachers at each pay scale in the 2015-2016 academic year, the corresponding pecuniary remuneration, and the total expenditure for the State, data that enabled us to determine the "average salary" paid by the State to primary and secondary teachers (elementary, middle, and high school teachers). Note that, in the 2015-2016 academic year, no teacher appeared in Scale 370, as it was a recently-created step and the first teachers were unable to access it due to the freezing of career steps within the scope of the austerity policies in force in Portugal at that time. 
TABLE 1

TEACHERS BY PAY SCALE AND TOTAL EXPENDITURE BY THE STATE IN 2015-2016

\begin{tabular}{|c|c|c|c|}
\hline $\begin{array}{c}\text { SCALES (TEACHERS } \\
\text { WITHIN THE FRAMEWORK) }\end{array}$ & $\begin{array}{c}\text { NUMBER OF } \\
\text { TEACHERS }\end{array}$ & $\begin{array}{c}\text { MONTHLY BASE } \\
\text { SALARY (EUROS) }\end{array}$ & $\begin{array}{c}\text { TOTAL EXPENDITURE/SCALE } \\
\text { (EUROS) }\end{array}$ \\
\hline Scale 167 & 9,833 & $1,518.63$ & $14,932,688.79$ \\
\hline Scale 188 & 13,361 & $1,709.60$ & $22,841,965.60$ \\
\hline Scale 205 & 17,912 & $1,864.19$ & $33,391,371.28$ \\
\hline Scale 218 & 14,090 & $1,982.40$ & $27,932,016.00$ \\
\hline Scale 223 & 57 & $2,027.87$ & $115,588.59$ \\
\hline Scale 235 & 7,163 & $2,137.00$ & $15,307,331.00$ \\
\hline Scale 245 & 8,490 & $2,227.93$ & $18,915,125.70$ \\
\hline Scale 272 & 5,064 & $2,473.46$ & $31,931,818.56$ \\
\hline Scale 299 & 11,744 & $2,718.99$ & $31,762,266.86$ \\
\hline Scale 340 & 10,273 & $3,091.82$ & 0 \\
\hline Scale 370 & 0 & $3,364.29$ & $\mathbf{2 0 9 , 6 5 5 , 7 7 3 . 8 0}$ \\
\hline Totals & 97,987 & & \\
\hline
\end{tabular}

Source: Prepared by the authors with data from the Ministry of Education (2018).

Taking into account the values in this table, it was possible to estimate the methodologically assumed reference value - the average salary - by dividing the total expenditure on the order of 209 million euros by the total of 97,987 teachers in the 2015/2016 academic year, thus arriving at the figure of 2,139.63 euros. 
TABLE 2

ANNUAL FINANCIAL OBLIGATIONS OF THE STATE / EMPLOYMENT COST OF AN AVERAGE SCALE TEACHER (BASED ON THE TOTAL NUMBER OF TEACHERS BETWEEN SCALES 167 AND 340) IN 2015-2016 (IN EUROS)

\begin{tabular}{|c|c|}
\hline PUBLIC FINANCIAL OBLIGATIONS & \\
\hline Monthly base salary (Average Salary) (1) & $2,139.63$ \\
\hline Social Security/CGA² (23.75\%) (2) & 508.16 \\
\hline Total monthly cost to the State $(1)+(2)$ & $2,647.79$ \\
\hline Annual total (14 months) ${ }^{3}(3)$ & $37,069.09$ \\
\hline Meal subsidy (11 months) $)^{4}(4)$ & $1,014.40$ \\
\hline Total Annual Obligation for a new teacher, hired at an average salary $(A)=(3)+(4)$ & $38,083.49$ \\
\hline \multicolumn{2}{|l|}{ DIRECT PUBLIC FINANCIAL BENEFITS } \\
\hline Total Annual Obligation (Average Salary) & $38,083.49$ \\
\hline Base salary (14 months) & $29,954.82$ \\
\hline IRS Withholding (22.2\%) (1) & $6,649.97$ \\
\hline Social Security/CGA (11\%) (2) & $3,295.03$ \\
\hline $\operatorname{ADSE}^{5}(3.5 \%)(3)$ & $1,048.42$ \\
\hline Total Direct Public Financial Benefits $(B)=(1)+(2)+(3)$ & $10,993.42$ \\
\hline \multicolumn{2}{|l|}{ INDIRECT PUBLIC FINANCIAL BENEFITS / ECONOMIC BENEFITS } \\
\hline Net Salary (Average Salary) (1) & $18,961.40$ \\
\hline Meal subsidy (11 months) (2) & $1,014.40$ \\
\hline Income from labour factor (RDP) (3) $=(1)+(2)$ & $19,975.80$ \\
\hline $\begin{array}{l}\text { Expected consumer spending ( } 96.1 \% \text { consumption tax, as a function of RDP-2nd } \\
\text { quarter 2016) }\end{array}$ & $19,196.74$ \\
\hline $\begin{array}{l}\text { VAT potential income ( } 12.5 \% \text { of the average VAT- VAT/Expected consumer } \\
\text { spending) (4) }\end{array}$ & $2,399.59$ \\
\hline Total Indirect Public Financial Benefits/Economic Benefits $(C)=(4)$ & $2,399.59$ \\
\hline $\begin{array}{l}\text { Average Net Annual Teacher Salary }=(A)-((B)+(C)) \\
\text { (Average Gross Annual Teacher Salary - Total Direct Public Financial Benefits } \\
\text { - Total Indirect Public Financial Benefits) }\end{array}$ & $\begin{array}{r}24,690.48 \\
\text { euros/ teacher } \\
\text { (Average Salary) }\end{array}$ \\
\hline
\end{tabular}

Source: Prepared by the authors with data from the Ministry of Education, Pordata and Banco de Portugal (2018).

It can therefore be seen that the State's annual obligations per teacher with an "average salary" are approximately 38 thousand euros. However, this burden soon decreases by about 11 thousand euros upon our taking into account the direct financial benefits to the State, as we add the corresponding amounts of IRS withholding, contributions to Social Security or CGA, and ADSE. In addition, if other indirect financial benefits are taken into account, the annual net salary will be on the order of 24,690.48 euros. Table 3 shows the same calculations applied to a teacher at the beginning of his or her career.

2 In the Portuguese context, Social Security refers to the general program, while Caixa Geral De Aposentacões (CGA) corresponds to the social security program for civil servants. Due to recent legal changes, some teachers are covered by CGA and others by Social Security.

3 In Portugal, in addition to their monthly salaries, workers receive a holiday bonus and a Christmas bonus.

4 In Portugal, the meal subsidy is only paid for 11 months of actual work.

5 The ADSE is a public institute of the Ministries of Finance and Health, directed toward Disability Protection and Assistance. 
TABLE 3

ANNUAL FINANCIAL OBLIGATIONS OF THE STATE/EMPLOYMENT COST OF SCALE 167 IN 2015-2016 (IN EUROS)

\begin{tabular}{|c|c|}
\hline PUBLIC FINANCIAL OBLIGATIONS & \\
\hline Base salary (Scale 167) (1) & $1,518.63$ \\
\hline Social Security / CGA (23.75\%) (2) & 360.67 \\
\hline Total monthly cost to the State $(1)+(2)$ & $1,879.30$ \\
\hline Annual total (14 months) (3) & $26,310.26$ \\
\hline Meal subsidy (11 months) (4) & $1,014.4$ \\
\hline Total Annual Obligation for a new teacher, hired at Scale $167(A)=(3)+(4)$ & $27,324.66$ \\
\hline \multicolumn{2}{|l|}{ DIRECT PUBLIC FINANCIAL BENEFITS } \\
\hline Total annual obligation (Scale 167) & $27,324.66$ \\
\hline Base salary (14 months) & $21,260.82$ \\
\hline IRS Withholding (15.8\%) (1) & $3,359.21$ \\
\hline Social Security / CGA (11\%) (2) & $2,338.69$ \\
\hline $\operatorname{ADSE}(3.5 \%)(3)$ & 744.13 \\
\hline Total Direct Public Financial Benefits $(B)=(1)+(2)+(3)$ & $6,442.03$ \\
\hline \multicolumn{2}{|l|}{ INDIRECT PUBLIC FINANCIAL BENEFITS / ECONOMIC BENEFITS } \\
\hline Net salary (Scale 167) (1) & $14,818.79$ \\
\hline Meal subsidy (11 months) (2) & $1,014.4$ \\
\hline Income from labour factor (RDP) (3) $=(1)+(2)$ & $15,833.19$ \\
\hline $\begin{array}{l}\text { Expected consumer spending ( } 96.1 \% \text { consumption tax, as a function of RDP-2nd } \\
\text { quarter } 2016 \text { ) }\end{array}$ & $15,215.70$ \\
\hline $\begin{array}{l}\text { VAT potential income ( } 12.5 \% \text { of the average VAT - VAT/Expected consumer } \\
\text { spending) (4) }\end{array}$ & $1,901.96$ \\
\hline Total Indirect Public Financial Benefits / Economic Benefits $(C)=(4)$ & $1,901.96$ \\
\hline $\begin{array}{l}\text { Net Annual Teacher Salary Scale } 167=(A)-((B)+(C) \text { ) } \\
\text { (Gross Annual Teacher Salary Scale } 167-\text { Total Direct Public Benefits - Total } \\
\text { Indirect Public Benefits) }\end{array}$ & $\begin{array}{r}18,980.67 \\
\text { euros/teacher } \\
\text { (Scale 167) }\end{array}$ \\
\hline
\end{tabular}

Source: Prepared by the authors with data from the Ministry of Education, Pordata and Banco de Portugal (2018).

As shown in Table 3, the State's total annual obligation for a teacher at Scale 167 (the entry-level salary step for a teacher) is approximately 27 thousand euros. However, this burden soon decreases by about 6,442 euros upon our taking into account the direct financial benefits to the State, as we add the corresponding amounts of IRS withholding, contributions to Social Security or CGA, and ADSE. In addition, if other indirect financial benefits were taken into account, the annual net salary would be on the order of 18,980.67 euros.

Considering the previous calculations, it is now possible, in Table 4, to summarize the different amounts projected.

TABLE 4

SUMMARY OF COSTS - FINANCIAL OBLIGATIONS OF THE STATE PER TEACHER, IN 2015-2016

\begin{tabular}{|c|c|}
\hline DESCRIPTION & EUROS \\
\hline Average Gross Annual Teacher Salary (euros) & $38,083.49$ \\
\hline Average Net Annual Teacher Salary (euros) & $24,690.48$ \\
\hline Gross Annual Teacher Salary Scale 167 (euros) & $27,324.66$ \\
\hline Net Annual Teacher Salary Scale 167 (euros) & $18,980.67$ \\
\hline
\end{tabular}

Source: Authors' development. 


\section{REAL FINANCIAL IMPACTS OF CLASS-SIZE REDUCTIONS IN PORTUGAL}

Drawing on a study commissioned by the Ministry of Education and carried out by a team of investigators concerning the impacts of class size reductions in the Portuguese educational system (CAPUCHA et al., 2017), we obtained the numbers presented in Table 5. In accordance with one of the proposed scenarios, we estimated not only the variation in the number of classes and teaching hours to be created at the national level (Full-time equivalent - ETI) ${ }^{6}$ if, in the academic year 2017/2018, the parameters of Normative Law 13765/2004 (DIÁRIO DA REPÚBLICA, 2018) were applied, but also the respective financial costs of teachers whom the State would need to hire.

TABLE 5

NUMBER OF CLASSES AND TEACHING HOURS TO BE CREATED IN 2017/2018

\begin{tabular}{|l|c|c|}
\hline \multicolumn{1}{|c|}{ STARTING YEARS OF THE CYCLE } & $\begin{array}{c}\text { CLASSES TO } \\
\text { CREATE }\end{array}$ & $\begin{array}{c}\text { TEACHING HOURS } \\
\text { TO CREATE (FTE) }\end{array}$ \\
\hline 1st year & 209 & 217 \\
\hline 5th year & 174 & 178 \\
\hline 7th year & 208 & 236 \\
\hline 10th year - Secondary Education (General) & 184 & 190 \\
\hline 1st year - Secondary Education (Professional) & 261 & 236 \\
\hline Totals & 1,036 & 1,057 \\
\hline
\end{tabular}

Source: Capucha et al. (2017).

As can be seen in Table 5, it is estimated that in 2017/2018 there would be an increase of 1,036 classes and 1,057 full-time schedules of teachers in the first year (the first cycle of primary education), the fifth year (the second cycle of primary education), the seventh year (the third cycle of primary education), the tenth year (secondary education), and the first year of professional/vocational courses (secondary education), if the aforementioned class-size reduction were implemented in the 2017/2018 academic year in Portugal. ${ }^{7}$

The estimates presented above are aggregate amounts that may undergo some modifications as a result of various factors, for example, a policy action that leads to a redistribution of students among oversized and undersized classes, or the implementation of transfers and reassignments that allow teachers without classes to teach in other schools where reduced class sizes would otherwise require new hires.

We emphasize once again that these estimates presuppose a possible replacement - on the part of current public decision makers - of the legal parameters of Normative Law 13765/2004 (DIÁRIO DA REPÚBLICA, 2018), that is, the legal framework in force between 2004 and 2013. Table 6 summarizes the different sizes of classes, in accordance with each educational cycle and the

6 T. N.: Local acronym for Equivalente a tempo integral.

7 It should be noted here that no consideration has been given to the dramatic fall in birth rates. Such fall introduces sufficient dynamics to change these figures significantly. 
relevant legislation since 2001 with respect to class size. In addition, the table indicates the average class size broken down for each educational cycle, taking into account the total number of classes in Portugal's school system, in the 2015-2016 academic year. It is worth adding that these are general rules and that there are other references designed for a number of specific settings, such as classes for students with special education needs.

\section{TABLE 6}

LEGISLATION ON CLASS SIZE IN PORTUGAL, FROM 2001 TO 2017, BY LEVEL OF INSTRUCTION

\begin{tabular}{|c|c|c|c|c|}
\hline EDUCATIONAL CYCLES & $\begin{array}{l}\text { LEGISLATION } \\
(2001-2004)\end{array}$ & $\begin{array}{l}\text { LEGISLATION } \\
(2004-2013)\end{array}$ & $\begin{array}{l}\text { LEGISLATION } \\
(2013-2017)\end{array}$ & $\begin{array}{l}\text { AVERAGE } \\
\text { CLASS SIZES } \\
\text { IN 2015-2016 }\end{array}$ \\
\hline $\begin{array}{c}\text { 1st cycle of } \\
\text { Primary Education }\end{array}$ & cannot exceed 25 & cannot exceed 24 & 26 students & $\begin{array}{c}20.7 \\
(16,142 \text { classes }) \\
\end{array}$ \\
\hline $\begin{array}{c}\text { 2nd cycle of } \\
\text { Primary Education }\end{array}$ & $25-28$ students & $24-28$ students & $26-30$ students & $\begin{array}{c}22.1 \\
(8,084 \text { classes }) \\
\end{array}$ \\
\hline $\begin{array}{c}\text { 3rd cycle of } \\
\text { Primary Education }\end{array}$ & $25-28$ students & $24-28$ students & $26-30$ students & $\begin{array}{c}22.4 \\
(11,772 \text { classes })\end{array}$ \\
\hline $\begin{array}{c}\text { Secondary Education } \\
- \text { General }\end{array}$ & $25-28$ students & $24-28$ students & $26-30$ students & $\begin{array}{c}24.5 \\
(7,008 \text { classes })\end{array}$ \\
\hline $\begin{array}{c}\text { Secondary Education } \\
\text { - Professional/Vocational } \\
\text { Classes }\end{array}$ & - & $\begin{array}{l}18-23 \text { (minimum of } \\
15 \text { and maximum } \\
\text { of } 28, \text { when justified) }\end{array}$ & $24-30$ students & $\begin{array}{c}17.2 \\
(3,583 \text { classes })\end{array}$ \\
\hline
\end{tabular}

Source: Capucha et al. (2017).

According to the projection in Table 5, the increase in full-time teacher hours by 1,057 would represent a gross cost to the State on the order of 29 million euros. Taking into account the amounts in Table 5 and, in addition, applying the estimated amounts in the methodological framework shown in Table 4, it was possible to obtain the following amounts, which are the financial impacts estimated for the 2017/2018 academic year, but at 2015-2016 prices.

TABLE 7

GROSS COSTS AND NET COSTS ARISING FROM TEACHING HOURS TO BE CREATED IN 2017/2018, PRICES IN 2015-2016

\begin{tabular}{|l|c|c|}
\hline \multicolumn{1}{|c|}{ YEARS OF THE BEGINNING OF EACH CYCLE } & $\begin{array}{c}\text { GROSS COSTS } \\
\text { (SCALE 167), } \\
\text { IN EUROS }\end{array}$ & $\begin{array}{c}\text { NET COSTS } \\
\text { (SCALE 167), } \\
\text { IN EUROS }\end{array}$ \\
\hline 1st year & $5,929,451.22$ & $4,118,805.39$ \\
\hline 5th year & $4,863,789.48$ & $3,378,559.26$ \\
\hline 7th year & $6,448,619.76$ & $4,479,438.12$ \\
\hline 10th year - Sciences \& Humanities Classes (General Education) & $5,191,685.40$ & $3,606,327.30$ \\
\hline 1st year - Professional/Vocational Classes & $6,448,619.76$ & $4,479,438.12$ \\
\hline Totals & $\mathbf{2 8 , 8 8 2 , 1 6 5 . 6 2}$ & $\mathbf{2 0 , 0 6 2 , 5 6 8 . 1 9}$ \\
\hline
\end{tabular}

Source: Authors' development.

From the analysis in Table 7, the evidence shows that, assuming the basic cost per teacher at Scale 167 in net terms - that is, 18,980.67 euros - instead of the 27,324.66 euros attached to the perspective of gross costs, the total real cost to the State is not almost 29 million euros but rather around 20 million euros, which represents a cost reduction on the order of $30 \%$. 
Therefore, the values presented clarify that the real cost to the State is significantly lower than that generally expected. Regardless of the fact that, in the Portuguese case, the reduction in the number of students per class may not require new hiring by virtue of demographic changes and administrative actions to redistribute students among oversized and undersized classes (the latter being about two-thirds of the total), our intention has been to show the fallacy of public decision-makers when they simply consider gross expenditures. Confined to their reductive viewpoints, these decision-makers frequently neglect the broader perspective of future positive externalities that result from a more educated population, as amply described in the literature.

\section{FINAL CONSIDERATIONS}

The aim of this work was to review the literature regarding class-size reduction policy, with a focus on its financial impacts, to present a methodological process that permits the assumption of some reference values for different pay scales of the teaching career, and to estimate more realistic costs for that policy, using the Portuguese educational system in 2015-2016 as a case study.

This article attempts to demonstrate, by means of the estimates presented, that there are benefits from reducing class sizes and that the associated costs are typically overestimated, as a result of being determined by the gross cost to the State of an additional employee, and not by the corresponding net costs, as we have made clear through the calculations presented.

Taking into account the projections of classes to create in the Portuguese educational system in the 2017/2018 academic year, we estimated that the net costs of this measure are on the order of 20 million euros, an amount significantly lower than those political decision-makers recurrently assume.

In fact, the net costs determined today may be, in the medium and long term, significantly lower than projected, or may even be null, by virtue of the positive externalities arising from education. Indeed, research has shown that, besides being more competent and productive, a more educated population shows more engagement and solidarity, is more open to change, has better hygiene and health habits, and is more discerning in terms of culture (WEALE, 1992; FARCHY; SAGOT-DUVAUROUX, 1994; WOLFE, 1995; WOLFE; ZUVEKAS, 1997; WOLFE; HAVEMAN, 2001). Therefore, education affects a number of elements that are difficult to measure monetarily but that have direct and indirect impacts on the economy, which thus justifies investing in it. Moreover, if all the monetary and non-monetary effects of education are taken into account, the cost of investing in it is marginally null.

In this sense, the reduction in the number of students per class should be seen as a highly profitable investment in the medium and long term, as it guarantees the development of a country and its people, as a result of the immediate pedagogical impact that it can have on student success. The promotion of a more educated and enlightened population, which is thus more skilled and 
productive, clearly justifies the investment and should be seen as more than just a financial burden, as political decision makers with limited, short-term perspectives have commonly seen it.

This work thus seeks to contribute to a broader and more refined reflection on these issues, not only in the context of the Portuguese educational system, but also in educational contexts of other countries, and, consequently, to sensitize different educational and political actors to the benefits and direct and indirect costs of a class-size reduction policy.

\section{REFERENCES}

BANCO DE PORTUGAL. Estatísticas do Banco de Portugal: indicadores económicos. Available in: https://www. bportugal.pt/indicadores?mlid=1042. Access in: 1 Mar. 2018.

BARDIN, Laurence. Análise de conteúdo. Lisboa: Edições 70, 2009.

BECKER, Gary. Human capital: a theoretical and empirical analysis, with special reference to education. Chicago: University of Chicago Press, 1964.

BLATCHFORD, Peter; CHAN, Kam; GALTON, Maurice; LAI, Kwok; LEE, Chi. Class size Eastern and Western perspectives. New York: Routledge, 2016.

BOGDAN, Robert; BIKLEN, Sari. Investigação qualitativa em educação: uma introdução à teoria e aos métodos. Porto: Porto, 1994.

CAPUCHA, Luís; CABRITO, Belmiro; CARVALHO, Helena; SEBASTIÃO, João; MARTINS, Susana da Cruz; CAPUCHA, Ana Rita; ROLDÃO, Cristina; TAVARES, Inês; MUCHARREIRA, Pedro Ribeiro. A dimensão das turmas no sistema educativo português. Lisboa: Ministério da Educação, 2017. Available in: https://www. portugal.gov.pt/pt/gc21/comunicacao/documento?i=a-dimensao-das-turmas-no-sistema-educativo-portugues. Access in: 29 Dec. 2017.

CHINGOS, Matthew. The impact of a universal class-size reduction policy: evidence from Florida's statewide mandate. Economics of Education Review, n. 31, p. 543-562, 2012.

DIÁRIO DA REPÚBLICA. Despacho Normativo n. 13765/2004. Available in: https://dre.pt/web/guest/pesquisa/-/ search/3118423/details/normal?q=13765\%2F2004. Access in: 4 abr. 2018.

FARCHY, Joëlle; SAGOT-DUVAUROUX, Dominique. L'économie des politiques culturelles. Paris: PUF, 1994.

FINN, Jeremy; ACHILLES, Charles. Tennessee’s Class-size study: findings, implications, misconceptions. Educational Evaluation and Policy Analysis, v. 21, n. 2, p. 97-109, 1999.

HANUSHEK, Eric. Assessing the effects of school resources on student performance: an update. Educational Evaluation and Policy Analysis Summer, v. 19, n. 2, p. 141-164, 1997.

HARFITT, Gary James. Class-size reduction: key insights from secondary school classrooms. Singapore: Springer, 2015.

JEPSEN, Christopher; RIVKIN, Steven. Class-size reduction and student achievement: the potential tradeoff between teacher quality and class size. Journal of Human Resources, v. 44, n. 1, p. 223-250, 2009.

KRUEGER, Alan. Experimental estimates of education production functions. The Quarterly Journal of Economics, v. 114, n. 2, p. 497-532, 1999.

KRUEGER, Alan. Economic considerations and class size. Economic Journal, n. 113, p. 34-63, 2003. 
MUCHARREIRA, Pedro Ribeiro; ANTUNES, Marina Godinho. Os efeitos das variáveis macroeconómicas no desempenho das organizações: evidência das pequenas e médias empresas em Portugal. Contabilidade \& Gestão - Portuguese Journal of Accounting and Management - Revista Científica da Ordem dos Contabilistas Certificados, n. 17, p. 113-143, 2015.

NORMORE, Anthony; ILON, Lynn. Cost-effective school inputs is class-size reduction the best educational expenditure for Florida? Educational Policy, v. 20, n. 2, p. 429-454, 2006.

PORDATA. Estatísticas de Portugal. Available in: https://www.pordata.pt/Portugal. Access on: 22 Feb. 2018.

PORTUGAL. Conselho Nacional de Educação. Organização escolar: as turmas. Lisboa: Conselho Nacional de Educação, 2016.

PORTUGAL. Ministério da Educação. Estatísticas da DGEEC. Available in: http://www.dgeec.mec.pt/np4/home. Access on: 16 Feb. 2018.

PSACHAROPOULOS, George. Returns to investment in education: a global update. World Development, v. 22, n. 9, p. 1325-1343, 1994.

PSACHAROPOULOS, George; PATRINOS, Harry Anthony. Returns to investment in education: a further update. Education Economics, v. 12, n. 2, p. 111-134, 2004.

SANT'OVAIA, Carlos; REIS, Rui Lopes. Retorno fiscal do investimento público na educação: caso do ensino secundário. Economia \& Empresa, n. 8, p. 118-153, 2008.

SCHULTZ, Theodore. Investment in human capital. American Economic Review, v. 51, n. 1, p. 1-17, 1961.

SERVE. Financing class-size reduction. Greensboro, NC: University of North Carolina School of Education, 2005.

WEALE, Martin. Externalities from education. In: HAHN, Frank (ed.). Recent developments in the economics of education. Aldershot: Edward Elgar Publishing Limited, 1992.

WHITEHURST, Grover; CHINGOS, Matthew. Class size: what research says and what it means for state policy. Washington D.C.: Brown Center on Education Policy, 2011.

WOLFE, Barbara. External benefits of education. In: CARNOY, Martin (ed.). International encyclopedia of economics of education. Cambridge: Pergamon, 1995. p. 159-163.

WOLFE, Barbara; HAVEMAN, Robert. Accounting for the social and non-market benefits of education. Wisconsin: Institute for Research on Poverty - University of Wisconsin-Madison, 2001.

WOLFE, Barbara; ZUVEKAS, Samuel. Non-market outcomes of schooling. International Journal of Education Research, n. 27, p. 491-502, 1997.

NOTE: All authors have contributed equally to this manuscript.

HOW TO CITE THIS ARTICLE:

MUCHARREIRA, Pedro Ribeiro; CABRITO, Belmiro Gil; CAPUCHA, Luís. Net costs of class-size reduction: the portuguese case. Cadernos de Pesquisa, São Paulo, v. 49, n. 172, p. 164-181, abr./jun. 2019. https://doi. $\operatorname{org} / 10.1590 / 198053145794$

\section{ERRATA}

\section{Para o artigo:}

MUCHARREIRA, Pedro Ribeiro; CABRITO, Belmiro Gil; CAPUCHA, Luís. Net costs of class-size reduction: the portuguese case. Cadernos de Pesquisa, São Paulo, v. 49, n. 172, p. 164-181, abr./jun. 2019. https://doi.org/10.1590/198053145794

Considerar as seguintes informações a respeito da tradução: 
1. The translation of this paper was supported by Portuguese national funds through FCT- Fundação para a Ciência e a Tecnologia, I.P., in the scope of the project reference UID/SOC/03126/2019.

2. TRANSLATED BY Lyn Miller-Lackman (Freelancer; lynml@me.com 
